\title{
NFKBIB wt Allele
}

National Cancer Institute

\section{Source}

National Cancer Institute. NFKBIB wt Allele. NCI Thesaurus. Code C52885.

Human NFKBIB wild type allele is located in the vicinity of 19q13.1 and is approximately 3 $\mathrm{kb}$ in length. This allele, which encodes NF-kappa-B inhibitor beta protein, is involved in the attenuation of the nuclear factor kappa B complex signaling pathway. 